\title{
Educational hypermedia in nursing assistance at birth: building and validation of content and appearance
}

\author{
Hipermídia educativa sobre assistência de enfermagem ao parto: construção e validação de conteúdo e aparência \\ Hipermedia educativa sobre asistencia de enfermería al parto: construcción y validación de contenido y apariencia
}

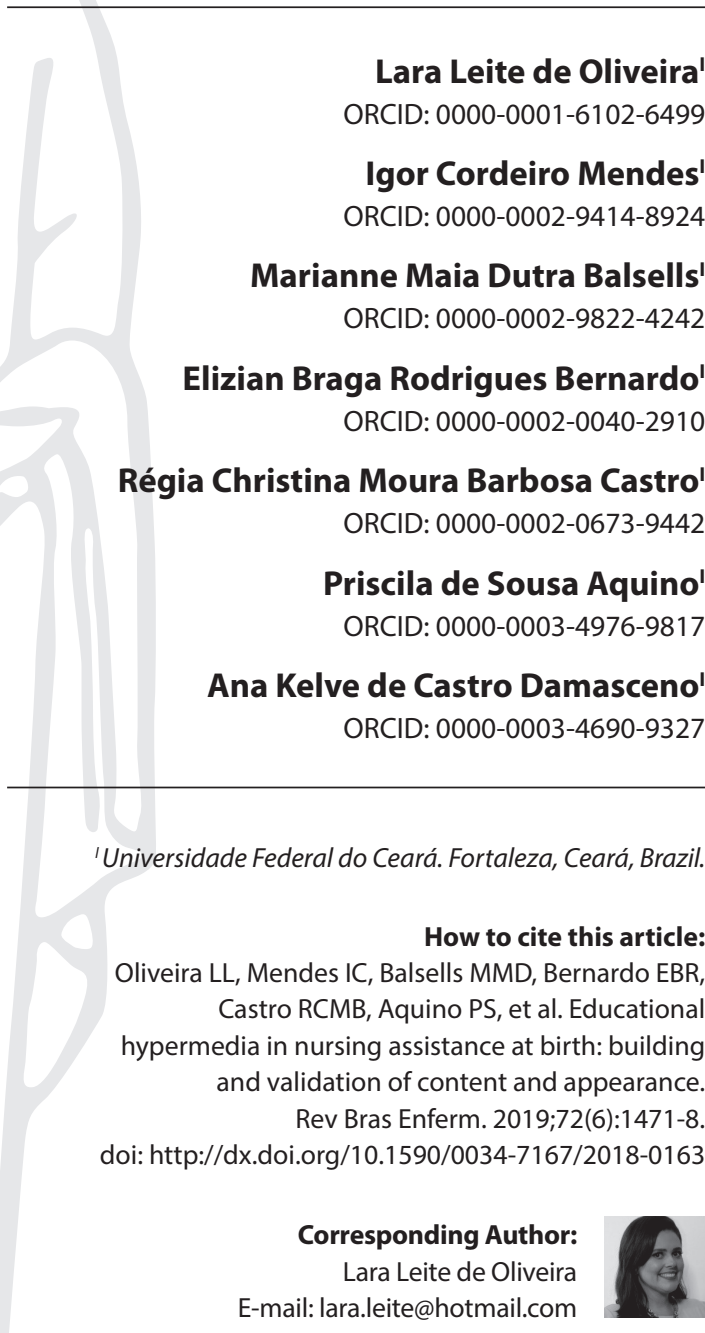

Submetido: 03-08-2018 Aprovado: 12-03-2018

\begin{abstract}
Objective: to build an educational hypermedia about nursing care at usual risk birth and to perform validation of content and appearance. Method: methodological research carried out following the following stages: content and planning of modules; media production and organization of tutorial units; organization of student space, tutor and communication between them; availability of hypermedia; assessment by experts in nursing and informatics; and implementation of proposed suggestions. Results: educational hypermedia showed to be a validated material, since it presented an optimum index of global content of 0.97 and statistical significance in the binomial test for the content and appearance. Conclusion: it is believed that the use of this material with undergraduate students in nursing will contribute to the quality of obstetric care, considering that it is an illustrated technology capable of favoring teaching-learning about normal humanized childbirth.

Descriptors: Hypermedia; Childbirth; Distance Education; Technology; Nursing.
\end{abstract}

\section{RESUMO}

Objetivo: construir uma hipermídia educativa sobre a assistência de enfermagem ao parto de risco habitual e realizar a validação de conteúdo e de aparência. Método: pesquisa metodológica, realizada seguindo as seguintes etapas: levantamento do conteúdo e planejamento dos módulos; produção das mídias e organização das unidades tutoriais; organização do espaço do aluno, tutor e de comunicação entre eles; elaboração da hipermídia; disponibilização da hipermídia; avaliação por especialistas em Enfermagem e Informática; e implementação das sugestões propostas. Resultados: a hipermídia educativa mostrou-se como um material validado, visto que apresentou um ótimo índice de validade de conteúdo global de 0,97 e significância estatística no teste binomial para o conteúdo e aparência. Conclusão: acredita-se que o uso deste material com alunos da graduação em Enfermagem contribuirá com a qualidade da assistência obstétrica, tendo em vista que se constitui em uma tecnologia ilustrada capaz de favorecer o ensino-aprendizagem sobre parto normal humanizado. Descritores: Hipermídia; Parto; Educação a Distância; Tecnologia; Enfermagem.

\section{RESUMEN}

Objetivo: construir una hipermedia educativa sobre la asistencia de enfermería al parto de riesgo habitual y realizar la validación de contenido y de apariencia. Método: investigación metodológica, realizada siguiendo las siguientes etapas: el levantamiento del contenido y la planificación de los módulos; la producción de los medios de comunicación y la organización de las unidades de tutoría; organización del espacio del alumno, tutor y de comunicación entre ellos; elaboración de la hipermedia; disponibilidad de la hipermedia; evaluación por especialistas en Enfermería e Informática; y aplicación de las sugerencias propuestas. Resultados: la hipermedia educativa se mostró como un material validado, ya que presentó un óptimo índice de validez de contenido global de 0,97 y significancia estadística en el test binomial para el contenido y apariencia. Conclusión: se cree que el uso de este material con alumnos de la graduación en Enfermería contribuirá con la calidad de la asistencia obstétrica, teniendo en vista que se constituye en una tecnología ilustrada capaz de favorecer la enseñanza-aprendizaje sobre parto normal humanizado. Descriptores: Hipermedia; Entrega; Educación a Distancia; Tecnología; Enfermería. 


\section{INTRODUCTION}

Women's health care during the gestational cycle remains a challenge for health authorities, both in terms of quality of care per se, and in conceptual frameworks ${ }^{(1)}$. With regard specifically to childbirth, in the course of time, various techniques, practices and care practices have been developed and improved, in order to humanize as much as possible the moment of childbirth and birth.

The meaning of normal humanized childbirth goes beyond its scientific definition as it is understood as a physiological and familiar event, being the role of the nurse to assist the woman so that this moment is as safe and pleasurable as possible ${ }^{(2)}$. Nonetheless, when there are risks to the mother-child binomial, cesarean section becomes the procedure of choice for the outcome of pregnancy.

The World Health Organization (WHO) advocates a cesarean rate of up to $15 \%$, which should be the maximum prevalence of caesarean section in any country in the world ${ }^{(3)}$. According to the research named "Nascer no Brasil: Inquérito Nacional sobre Parto e Nascimento" performed in 2012 by Fiocruz, 52\% of deliveries in Brazil were cesarean, with $46 \%$ in the Public Sector and $88 \%$ in the Private Sector. The Northeast is one of the regions with the highest rates, reaching 35 to $40 \%$. It is estimated that in Brazil, almost one million women are submitted every year to cesarean section without adequate obstetric indication ${ }^{(4)}$.

In view of the need for greater attention to maternal and child health, the Millennium Development Goals Report aims to reduce child mortality and improve maternal health ${ }^{(5)}$. By 2030, the overall rate of maternal mortality is expected to be reduced to less than 70 deaths per 100,000 live births; with the aim of reducing neonatal mortality to at least 12 per 1,000 live births ${ }^{(6)}$.

Government policies and actions were implemented at the federal, state and municipal levels, with the aim of encouraging pregnant women to perform normal childbirth, as well as guiding health professionals to encourage this practice, aiming to reduce the high cesarean rates throughout the Brazilian territory. These policies include the Programa de Humanização no Pré-natal e Nascimento (freely translated as Prenatal and Birth Humanization Program), the Pacto Nacional pela Redução da Mortalidade Materna (freely translated as Brazilian Pact for Reducing Maternal Mortality), and the Stork Network, with the objective of encouraging normal childbirth, improving the quality of childbirth care and demystify fear of normal birth in the country. However it is clear that even with the creation of all these policies, rates of cesarean childbirth remain high $^{(7-9)}$.

In view of this new setting of normal childbirth care, there is a need for qualified professionals to provide humanized care for women during this period, based on good practices of care for childbirth and birth, putting into action midwifery care supported in the best scientific evidence. The graduate nurse is one of them, since he is able to provide nursing care for the pregnant woman, the parturient woman, the puerperal woman and the newborn, and can perform obstetric care and assistance in an emergency situation and perform childbirth without dystocia, according to the Decree-Law 94,406 of June $8,1987^{(10)}$.

Thus, the need for graduates and experts with a well-established clinical vision is fundamental for normal childbirth to be assisted in a satisfactory way and for this it is essential that health professionals be trained and updated. Nursing education in Brazil is included in these transformations, where several phases of its development over the years. Informatics and the internet have contributed to these changes that have taken place in the teaching-learning process. Since the beginning of the twentieth century, Distance Education (DE) has been in an accelerated development process, giving students the opportunity to better access information through new Information and Communication Technologies in Health (ICT). This type of education has been modernized and spread throughout the country, in the various courses in the area of Health, especially in nursing ${ }^{(11)}$.

Currently, DE can be made available in a variety of ways, among them hypermedia, which can be presented as software or Virtual Learning Environments (VLE). These resources are understood as relevant because they allow students to train, interact, know new technologies and enter into a new virtual reality. VLE consist of dynamic spaces and make the teaching-learning process more creative, interesting and powerful.

Therefore, teachers and students now have a more active participation in the teaching-learning process insofar as they interact virtually in the proposed activities, as well as in the course of the discipline. In Ceará State, its Federal University has been using $D E$ for some years, both for short courses and for complete undergraduate ${ }^{(12-16)}$.

Considering that normal humanized childbirth has been widely encouraged and that the nurse/midwife has the role of assisting and performing this type of childbirth, it is important to increase the interest in the building of innovative technologies that address this content to help the training and qualification of these nurses, thus forming new generations of these professionals.

In view of the above, it is relevant to create and validate an educational hypermedia focused on childbirth care, because it is believed that there will be a greater deepening of students regarding this subject, since they will have more contact with the subject and will experience situations of practice simulated through the VLE. With the more qualified preparation of these future nurses, it is expected that these professionals are more apt, prepared and confident to provide a satisfactory nursing care for the parturient.

\section{OBJECTIVE}

To build an educational hypermedia about nursing care at usual risk birth and to perform validation of content and appearance.

\section{METHOD}

It is a methodological research, applied, of technological production. An educational hypermedia was developed, in the form of a website, entitled: "Assistência de Enfermagem aos Períodos Clínicos do Parto", available from: http://www.assistenciaaoparto. com.br. It, was developed in two phases: building and validation, being one of content (by midwives) and the other of appearance (by informatics).

The methodological path of hypermedia building and validation followed the stages presented in Figure 1. 


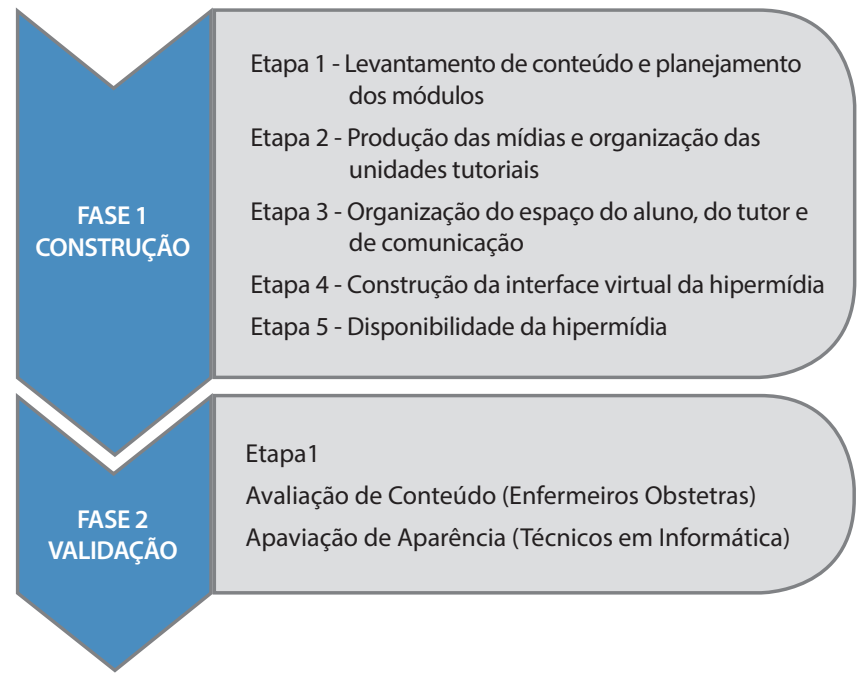

Figure 1 - Model-synthesis of a methodological path for the building of hypermedia, Fortaleza Ceará, Brazil, 2019

The first phase of the study has the building of educational technology and was carried out in five stages described below:

In the first stage, the contents of the Assistência de Enfermagem aos Períodos Clínicos do Parto were surveyed, with the selection of scientific productions of textbooks in the field of obstetrics, technical manuals of the Brazilian Ministry of Health and the World Health Organization, and articles published in Brazilian and international journals. The databases used for the content survey were the following: LILACS (Latin American \& Caribbean Literature in Health Sciences), PubMed (Public/Publish Medline), CINHAL (Cumulative Index to Nursing and Allied Health Literature), Scopus and Cochrane, in addition to sites of the Ministry of Health. Next, there was the planning of the modules that would be addressed in hypermedia.

The second stage was the media production. Both static media (texts, images, flowcharts, books and articles) and dynamics (videos and website links) were used. Some were selected from sources of public domain information, others produced during the development of this study (videos, images and texts) in the Laboratório de Habilidades (LABHAB - freely translated as Laboratory of Skills) of the Department of Nursing of the Universidade Federal do Ceará (UFC).

The third, fourth and fifth stages were, respectively, the preparation of the communication space of the student and tutor (message space, chats and discussion forums), the preparation of the material in the VLE and its availability from: http://www.assistenciaaoparto.com.br.

The second phase deals with the validation of appearance (midwives) and content (IT technicians). For the calculation of the number of experts, a sample of the non-probabilistic and intentional type was used. Calculation's estimate was based on the infinite population formula, with the statistical criteria being a minimum proportion of $85 \%$ of concordance with the pertinence of each evaluated item. There was a $15 \%$ difference in this concordance. Thus, the sample size was defined according to the following calculation: $n=Z a^{2}$.P. (1-P)/ $d^{2}$, where $Z a$ is the confidence coefficient $(95 \%-1.96), P$ is the individuals' proportion $(85 \%)$ and $d$ is the difference to be detected.

Final calculation was determined by $\mathrm{n}=1.962 \times 0.85 \times 0.15 / 0.152$ and, therefore, the sample consisted of 22 experts ${ }^{(17)}$. Of these,
11 were for the midwifery area (content validation) and 11 were for the area of informatics (validation of appearance).

The selection of experts of the two fields was via Curriculum Lattes or by indication of other professionals of the area, following the following criteria:

Chart 1 - Criteria for selection of experts in midwifery and informatics, Fortaleza, Ceará, Brazil, 2019

\begin{tabular}{|l|c|}
\hline \multicolumn{1}{|c|}{ MIDWIFERY EXPERT } & SCORE \\
\hline Doctorate or Masters in nursing & 3 points \\
\hline Thesis or dissertation on obstetrics & 3 points \\
\hline Specialization or Residency in midwifery & 2 points \\
\hline Undergraduate or specialization monograph on obstetrics & 0.5 point \\
\hline $\begin{array}{l}\text { Participation in groups/research projects that involve } \\
\text { obstetrics }\end{array}$ & 0.5 point \\
\hline $\begin{array}{l}\text { Authorship in work published in journals on obstetrics, in } \\
\text { the last three years }\end{array}$ & 0.5 point \\
\hline Teaching experience in obstetrics & 3 points \\
\hline Practice in obstetrics & 3 points \\
\hline Orientations of work on obstetrics & 1 point \\
\hline Participation in stands evaluating work involving obstetrics & 0.5 point \\
\hline & SCORE \\
\hline INFORMATICS EXPERT & 3 points \\
\hline Doctorate or Masters in informatics & 3 points \\
\hline Scientific production on Distance Education & 2 points \\
\hline Professional experience in VLE development & 3 points \\
\hline Professional experience in website development & 3 points \\
\hline Specialization in the area of website development & 3 points \\
\hline
\end{tabular}

For the selection of experts in midwifery, a minimum score of 5 points was adopted and, for Informatics, 3 points, based on the criteria adopted by Barbosa ${ }^{(18)}$ and Freitas ${ }^{(12)}$. The average score of the experts in nursing was of 8.5 , being the minimum score 6 and the maximum of 14 . The average of Informatics experts, was of 7.5 , with the minimum of 5 points and the maximum of 12 points.

Thirty-four midwives and 19 IT professionals were invited to participate in the study, of which 13 nurses and 14 informatics professionals answered. To compose the sample of 22 expert judges, the first 11 of each group who answered the questionnaire were selected within the term requested by the researcher.

For the data collection, assessment instruments of the educational hypermedia were used that assigned to each assessment criterion a concept arranged in a scale of the type Likert, with the following score: (1) Inadequate, (2) Poorly Adequate, (3) Fairly Adequate and (4) Fully adequate, as well as a space for suggestions.

The data filled in the forms by the experts were tabulated and analyzed statistically, using the software, Statistical Package for the Social Sciences (SPSS), version 24.0. In the analysis of the data, two tests were carried out for content validation: the 
Content Validity Index (CVI), with a minimum acceptable level of concordance of $78 \%{ }^{(19)}$ and the binomial test for adequacy of the adjustment, considering a proportion of $85 \%$ of the experts as concordant. For the validation of appearance, only the binomial test was used, which considered the level of significance $p$ of $5 \%$ to reject the null hypothesis, where the values of $p<0.05$ were considered as statistically significant ${ }^{(20)}$. After the assessment of the nursing and informatics experts, the suggested changes were made and forwarded for a new appreciation and finalization of the validation with the appropriate adjustments.

The study was submitted to the Ethics in Research Committee of the Universidade Federal do Ceará and approved under Protocol 931,300 . The norms of Resolution 466/12, of the Ministry of Health, were respected for research involving human beings, and all participants were asked to sign the Free and Informed Consent Form (FICF).

\section{RESULTS}

\section{Hypermedia building}

The hypermedia was built according to the Nursing Assistance provided to the clinical periods of the childbirth. The content was arranged as follows: a "Main Menu" at the top containing "Presentation" (with the link to the page of signs preceding childbirth), "Module I" ( $1{ }^{\text {st }}$ Clinical Period of Childbirth - Dilation), "Module II" (2 ${ }^{\text {nd }}$ Clinical Period of Childbirth - Expulsion), "Module III" ( $3^{\text {rd }}$ Clinical Period of Childbirth - Detachment), "Module IV" $\left(4^{\text {th }}\right.$ Clinical Period of Childbirth - Greenberg), "References" (containing all the references used in the hypermedia content survey) and "Extra videos".

And two secondary"Menus" on the left side, the first, called "Modules", containing the same links as the "Main Menu"and the second, called "Information", containing "Agenda" (where the tutor will post the schedule of activities for each semester), "Checklist" (containing a summary for Nursing Assistance to Normal Childbirth at Habitual Risk in a checklist), "Support Material" (containing the links to the main technical manuals related to obstetrics, used nationally and internationally), "Forum,, "Chat", "Assessment" and "Glossary".

The media elaborated by the research and used in the educational technology (videos, photos, forums, texts, among others) were arranged in each module according to the need of each one, as shown in Figure 2.

Module I: $1^{\text {st }}$ Clinical Period of Childbirth, dilatation was divided into four topics: Topic 01: Concepts of the $1^{\text {st }}$ Clinical Period of Childbirth: Dilation; Topic 02: Diagnosis of Childbirth; Topic 03: Admission of the Pregnant Woman at the Normal Childbirth Center and Topic 04: Nursing Assistance at the $1{ }^{\text {st }}$ Clinical Period of Childbirth.

Module II: $2^{\text {nd }}$ Clinical Period of Childbirth, expulsion was divided into two topics: Topic 01: Concepts of the $2^{\text {nd }}$ Clinical Period of Childbirth: Expulsion and Topic 02: Nursing Assistance to the $2^{\text {nd }}$ Clinical Period of Childbirth.

Module III: $3^{\text {rd }}$ Clinical Period of Childbirth, split was divided into two topics: Topic 01: Concepts of the $3^{\text {rd }}$ Clinical Period of Childbirth: Detection and Topic 02: Nursing Assistance to the $3^{\text {rd }}$ Clinical Period of Childbirth.

Module IV: Fourth Clinical Period of Childbirth, Greenberg was divided into two topics: Topic 01: Context and Main concepts of the $4^{\text {th }}$ Clinical Period of Childbirth: Greenberg and Topic 02: Nursing Assistance to the $4^{\text {th }}$ Clinical Period of Childbirth.

The hypermedia built in this study has an assessment of the learning at the end of each of the four modules. Assessment was focused on clinical cases related to the possible reality that the student finds in his practice. It is believed that this type of assessment will boost the clinical and critical reasoning of the student to possible situations of their daily practice.

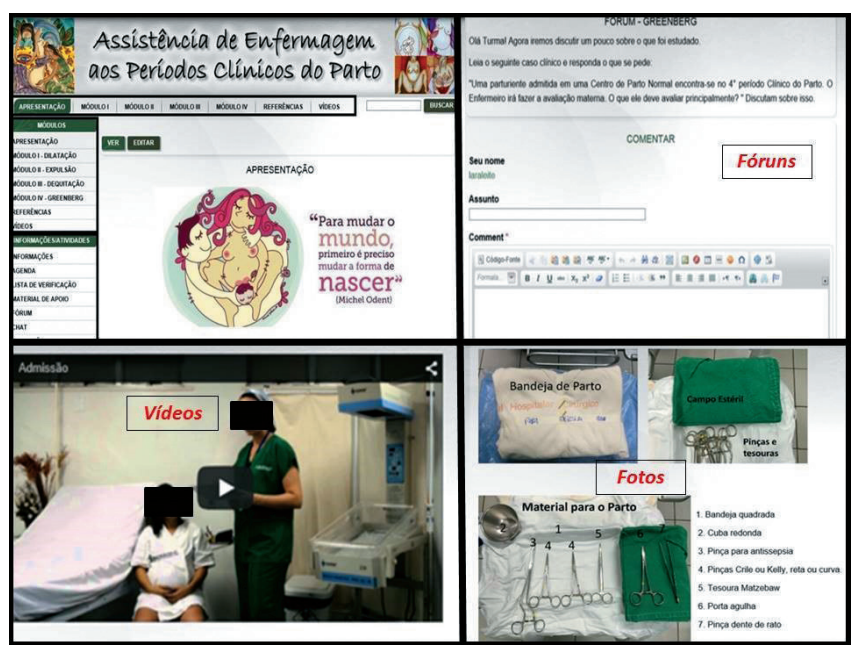

Figure 2 - Illustrative of media present in hypermedia, Fortaleza, Ceará, Brasil, 2019

It is noteworthy that, during the hypermedia content survey phase, some materials were selected to be made available in full in order to expand the participants' knowledge about the topic. These were made available in a"Secondary Menu" item, hyperlink: Support Material and within the text of Hypermedia Modules. It is worth emphasizing that the availability of hypermedia will give undergraduates, outside the classroom environment, flexible hours to complement their training. This material is provided as a form of support for undergraduate education.

\section{Content Validation by experts in midwifery}

The 11 midwives were professionals inserted in the practice, teaching and/or obstetric health research. They assessed whether the educational objectives were reached by the hypermedia produced, as well as the interface of the proposed content, the relevance to nursing practice and the use of the hypermedia environment.

Regarding the assessment of the educational objectives were consistent with the nursing practice, the two tests performed showed good results. All values of the items were significant in the binomial test, since the proportion values among the experts were above $85 \%$ and the $p=0.001$, as well as the CVI values were higher than 0.78 , which makes this item valid.

Concerning the content of hypermedia, it also presented an effective assessment, since the proportion values in the binomial test among the experts were greater than $85 \%$ ( $p$ between 0.001 and 0.012 ), as well as CVI values were higher than 0.78 and therefore this item was considered valid. Nonetheless, there were suggestions from the experts to improve the content presented. 
Table 1 - Distribution of hypermedia assessment by midwives regarding goals, content, relevance and environment ( $\mathrm{n}=11$ ), Fortaleza, Ceará, Brasil, 2019

\begin{tabular}{|c|c|c|c|}
\hline VARIABLES & Proportion & $p$ value* & $\mathrm{CVI}^{* *}$ \\
\hline \multicolumn{4}{|l|}{ Objectives } \\
\hline 1. They are consistent with nursing practice. & 1.00 & 0.001 & 1.00 \\
\hline 2. The content presented in the hypermedia facilitates the teaching-learning process in the theme. & 1.00 & 0.001 & 1.00 \\
\hline 3. The proposed objectives are adequate to be effective. & 1.00 & 0.001 & 1.00 \\
\hline \multicolumn{4}{|l|}{ Content } \\
\hline 1. The content accurately addresses the topic. & 1.00 & 0.001 & 1.00 \\
\hline 2. The information presented is correct. & 1.00 & 0.001 & 1.00 \\
\hline 3. Simulations are compatible with reality. & 0.91 & 0.012 & 0.90 \\
\hline 4. Images correctly illustrate what was mentioned in the text. & 1.00 & 0.001 & 1.00 \\
\hline 5. It is adequate for nursing undergraduates. & 1.00 & 0.001 & 1.00 \\
\hline 6. The language used is accessible to users. & 0.91 & 0.012 & 0.90 \\
\hline 7. Complies with nursing practice in childbirth room. & 1.00 & 0.001 & 1.00 \\
\hline 8. Hypermedia presents a sufficient number of classes and topics, in adequate division. & 1.00 & 0.001 & 1.00 \\
\hline \multicolumn{4}{|l|}{ Relevance } \\
\hline 1. Items illustrate aspects important to nursing practice at clinical periods of childbirth. & 1.00 & 0.001 & 1.00 \\
\hline 2. Forums are relevant so that the student can complement their knowledge. & 0.91 & 0.012 & 0.90 \\
\hline 3. The items are relevant so that the user can carry out activities with better performance. & 1.00 & 0.001 & 1.00 \\
\hline \multicolumn{4}{|l|}{ Environement } \\
\hline 1. The website is adequate for submission of content. & 1.00 & 0.001 & 1.00 \\
\hline 2. Resources are adequate for learning the theme. & 0.90 & 0.012 & 0.90 \\
\hline 3. Resources provide learning situations. & 0.90 & 0.012 & 0.90 \\
\hline
\end{tabular}

Note: *Binomial test; ** Content Validity Index (CVI).

Regarding the relevance of the items presented in educational hypermedia, the experts evaluated as "very good" and "relevant", since the values of the proportion in the binomial test between them were higher than $85 \%$ ( $p$ between 0.001 and 0.012) and $\mathrm{CVI}$ values were higher than 0.78 , thus making this item also valid. Relevance of the theme was highlighted in the observations, considering the current Stork Network Strategy of the federal government, which encourages nursing care for normal childbirth. Nonetheless, some suggestions were also proposed to improve hypermedia.

Regarding the environment, the items were considered valid, considering that the values of the binomial proportion between them were higher than $85 \%$ ( $p$ between 0.001 and 0.012 ), and the CVI values were higher than 0.78 .

As shown below, the overall CVI of hypermedia was 0.97 , thus being considered the same validated in content by midwives.

In order to analyze the suggestions proposed, a commission was formed of three researchers who used the latest scientific evidence to follow or not what was proposed by the experts.
When two or more of them agreed, the suggestion was accepted and the changes were made in hypermedia. This is necessary because the procedure of assessment of educational technology to the suggestions of the experts is an important phase to make the construct complete, with greater scientific rigor and effectiveness, during the activity that the same is proposed.

\section{Validation of appearance by informatics experts}

The 11 ITs who participated in the process of validating the appearance of this hypermedia evaluated the functionality, usability and efficiency.

In relation to the functionality of hypermedia, it was evaluated as a adequate tool for the proposal with a proportion above $85 \%$ $(p=0.001)$, in the two topics of this item, making it valid. Functionality requirements of a hypermedia interface help to verify that the website makes it easier for users to achieve their goals by visiting it, whether the incidence of errors is acceptable and how they are faced.

Table 2 - Distribution of hypermedia assessment by informatics experts regarding functionality, viability and efficiency ( $\mathrm{n}=11$ ), Fortaleza, Ceará, Brasil, 2019

\begin{tabular}{|c|c|c|}
\hline VARIABLES & Proportion & $p$ value* \\
\hline \multicolumn{3}{|l|}{ Funcionality } \\
\hline 1. Hypermedia is presented as an appropriate tool for the purpose of the proposal. & 1.00 & 0.001 \\
\hline 2. Hypermedia makes it possible to generate positive results. & 1.00 & 0.001 \\
\hline \multicolumn{3}{|l|}{ Usability } \\
\hline 1. Hypermedia is easy to use. & 0.91 & 0.012 \\
\hline 2. It is easy to learn the concepts used and their applications. & 0.91 & 0.012 \\
\hline 3. It allows control of the activities presented there, being easy to apply. & 1.00 & 0.001 \\
\hline 4. It allows the user to easily apply the concepts worked. & 0.91 & 0.012 \\
\hline 5. It provides clear help. & 1.00 & 0.001 \\
\hline 6. It provides complete help. & 1.00 & 0.001 \\
\hline 7. It provides help quickly, not tiring. & 0.91 & 0.012 \\
\hline
\end{tabular}




\begin{tabular}{|c|c|c|}
\hline VARIABLES & Proportion & $p$ value* \\
\hline \multicolumn{3}{|l|}{ Efficiency } \\
\hline 1. Hypermedia design is adequate for use. & 0.91 & 0.012 \\
\hline 2. The number of classes is consistent with the proposed time. & 0.55 & 1.000 \\
\hline $\begin{array}{l}\text { 3. Organization of the thematic topics is adequate for the good understanding of the content, as well as the easy } \\
\text { location of the desired theme. }\end{array}$ & 1.00 & 0.001 \\
\hline 4. Resources are used properly. & 1.00 & 0.001 \\
\hline 5. Resources are used efficiently and comprehensibly. & 0.91 & 0.012 \\
\hline
\end{tabular}

Note: *Binomial test.

In the "usability" item, hypermedia was considered easy to use and to learn the concepts used, providing help in a clear, complete, concise and fast, with a proportion above $85 \%$ ( $p$ between 0.001 and 0.012 ) valid. Nonetheless, it was suggested that when you mouse over the module and topic links, the title of the modules and topics should appear and that at the end of each page there should be a link to "go to the top". The suggestions were followed. This evaluative question becomes important, as it verifies how much the hypermedia will be able to be viable in the teaching-learning context in which the student is inserted.

The "efficiency" item also presented a significant proportion, above $85 \%$ ( $p$ between 0.001 and 0.012 ), except for "The number of classes is consistent with the proposed time", which presented a proportion of $55 \%(p=1.000)$. In this item, it was referred by three informatics experts that the proposed class time was small for the size of the content worked. It was suggested by them that the content be diluted in a longer time.

Thus, as in the validation of content, for the validation of appearance with informatics experts, a commission of three researchers was formed and the same criteria mentioned above were used to analyze the proposed suggestions.

\section{DISCUSSION}

As shown above, hypermedia was considered valid according to midwives and informatics experts, who evaluated the content and appearance respectively.

As a suggestion of improvement regarding the objectives, it was proposed by an expert to include other contexts of nursing care at childbirth such as house of childbirth, home birth and presence of doula. The suggestion is quite valid, but it was not accepted, because it would defocus from the initially proposed objective, which is the nursing assistance to the parturient in a normal childbirth center.

For organization of the objectives of a digital educational technology, one must take into account the intended audience, the user's familiarity with the contents of the virtual environment to be projected, the organization of the flow chart and, consequently, the objectives listed ${ }^{(16)}$.

In this sense, researchers point out that the proposed objectives should be clear and concise, since they aim to guide the instructional design and assist in the assessment of the teaching-learning process ${ }^{(17)}$. Another relevant aspect is whether the proposed objectives will actually be achieved. To do so, the description of the objectives should be at the beginning of the classes, because it facilitates the understanding of the content by the students and favors feedback at the end of the lesson ${ }^{(18)}$.
Regarding the content, an expert mentioned that in topic 02 of Module II, the illustrative images do not present the alloys but rather the clamp, nonetheless, in the text, it is mentioned that two alloys should be used to clamp the cord. The suggestion was accepted and included in the hypermedia image of alloys, and the information that there are two forms for the clamping of the cord.

Another expert pointed out that in topic 02 of Module II, the use of Personal Protective Equipment (PPE) could be placed as an option. He justifies that, in humanized behavior, childbirth is considered as "non-pathological" and therefore does not require all PPE. He also points out that antisepsis of the genital region with PVPI and clorexidine should also be optional, since, according to him, many nurses follow alternative procedures with the hygiene of the region with soap and water. The suggestion was accepted, the initial conduct was maintained. Nonetheless, the expert's suggestion was placed as observation.

The third expert suggested that in topic 2 of Module II, the term "Uterine Dynamics Technique" be changed to "Uterine Dynamics Assessment Technique". The suggestion was followed and the name of the technique was changed in hypermedia.

The purpose of content evaluation is to determine whether learners will acquire the knowledge or techniques taught through the content available as well as verify its quality ${ }^{(19)}$. In this sense, the content presented in VLE must follow a logical sequence, with a self-explanatory and dynamic approach ${ }^{(20)}$.

A serial album, regarding self-efficacy in breastfeeding, was validated in terms of content, presenting a global CVI of 0.92, being evaluated by ten judges, with well-known knowledge in education and/or breastfeeding ${ }^{(21)}$.

In terms of relevance, one expert suggested that the description of the conduct of the episiotomy, when and how to perform it. The suggestion, although relevant, was not accepted, since nursing undergraduate students of hypermedia are the target audience, and this procedure can only be performed by midwives.

Another expert pointed out that forums for discussion of clinical cases are very relevant and suggested that more forums be added with real clinical cases to boost clinical and critical thinking of students in different situations. The suggestion was followed and other clinical case forums were created in hypermedia.

A serial album regarding self-efficacy in breastfeeding was validated in terms of content, presenting a global CVI of 0.92, being evaluated by ten judges, with well-known knowledge in education and/or breastfeeding ${ }^{(21)}$.

Regarding the assessment of the virtual environment, it was similar regarding the VLE assessment criteria, since experts 
evaluated the response time, the interface quality, the tools, the educational aspects, the quality of the environment and the adequate didactic resources to the environment, providing learning situations ${ }^{(22)}$.

In the teaching-learning process, the functionality of the interface refers to the clarity of the links, the ease of scrolling between pages and processes, the ease of finding information, the proper presentation of content and the performance of tasks by users without errors and problems ${ }^{(23)}$.

Only $66 \%$ of users complete the tasks that they propose when they visit websites. In the establishment of assessment references, he suggests that if $70 \%$ of the assessments about this domain are positive, the site is able to be published effectively ${ }^{(24)}$.

In this sense, to verify the usability of a technology is to verify the extent to which a product can be used by specific users to reach specific objectives with effectiveness, efficiency and satisfaction, in a specific use context. In general, usability studies in Information Sciences propose to be an instrument to enable the development and/or adequacy of information systems from a user-centered perspective, their needs, tasks to be performed, conditions of interaction with the system, among other factors ${ }^{(25-30)}$.

Nonetheless, this evaluative question becomes important as it verifies how much hypermedia will be able to be viable in the teaching-learning context in which the student is inserted.

\section{Study limitations}

As a limitation of this study, one can cite the non-validation by the target audience and nursing professionals. Having completed the building and validation of hypermedia, the study does not end here as it is emphasized that hypermedia will undergo continuous updates through scientific progress.

\section{Contributions to the field of Nursing}

It is emphasized that the hypermedia building stages require time and effort on the part of the researcher, but they result in obtaining a satisfactory material for teaching activities, and should therefore be produced in greater quantity and quality, seeking to satisfy the needs of a more didactic learning for nursing undergraduates.

\section{CONCLUSION}

Regarding the building of this technology, the model used was considered adequate, in order to really contemplate the necessary stages for the building of an educational material like the one produced in this study.

The developed educational hypermedia presents evidence of validity of appearance and content, since it presented a good overall CVI (0.97) from the validation by the judges and level of concordance regarding the significant appearance through the binomial test, with $p$ varying from 0.001 to 0.012 . It should be considered in the context of nursing undergraduate teaching practices as an instrument capable of promoting learning regarding parturition assistance during normal humanized childbirth.

The use of this material with nursing students would facilitate normal childbirth care at usual risk, considering that it is an interactive technology capable of favoring the teaching-learning process of students, facilitating the acquisition of its knowledge, memorizing the necessary care for the woman patient, as well as a means of systematizing the recommendations to be followed by the midwilfe.

\section{FUNDING}

Universidade Federal do Ceará. Centro Universitário Católica de Quixadá.

\section{REFERENCES}

1. Balsells MMD, Oliveira TMF, Bernardo EBR, Aquino PS, Damasceno AKC, Castro RCMB, et al. Avaliação do processo na assistência pré-natal de gestantes com risco habitual. Acta Paul Enferm. 2018;31(3):247-54. doi: 10.1590/1982-0194201800036

2. Di Renzo GC, Gerli S, Fonseca E. Manual Prático de Ginecologia e Obstetrícia para Clínica e emergência: on The Road. São Paulo: Elsevier; 2017.

3. World Health Organization (WHO). United Nations Population Fund. United Nations Children's Fund. Mailman School of Public Health. Monitoring emergency obstetric care: a handbook [Internet]. Geneva:WHO; 2009 [cited 2018 Feb 2]. Available from: https://apps.who.int/ iris/handle/10665/44121

4. Leal MC, coordenadora. Nascer no Brasil: Inquérito Nacional sobre Parto e Nascimento. Sumário Executivo Temático da Pesquisa [Internet]. Rio de Janeiro: Fundação Oswaldo Cruz; 2012 [cited 2018 Feb 2]. Available from: http://www.ensp.fiocruz.br/portal-ensp/informe/site/ arquivos/anexos/nascerweb.pdf

5. United Nations (UN). The Millenium Development Goals Report 2014 [Internet]. New York: UN; 2015 [cited 2018 Feb 2]. Available from: https://www.un.org/millenniumgoals/2014\%20MDG\%20report/MDG\%202014\%20English\%20web.pdf

6. United Nations (UN). Transforming our world: The 2030 Agenda for Sustainable Development [Internet]. New York: UN; 2015. [cited 2018 Feb 2]. Available from: https://sustainabledevelopment.un.org/content/documents/21252030\%20Agenda\%20for\%20Sustainable $\% 20$ Development\%20web.pdf

7. Pavanatto A, Alves LMS. Programa de humanização no pré-natal e nascimento: indicadores e práticas das enfermeiras. Rev enferm UFSM. 2014;4(4):761-70. doi: 10.5902/2179769211329

8. Pinheiro JMF, Tinoco LS, Rocha ASS, Rodrigues MP, Lyra CO, Ferreira MAF. Childcare in the neonatal period: evaluation of neonatal mortality reduction pact in rio Grande do Norte, Brazil. Ciênc Saúde Colet. 2016;21(1):243-52. doi: 10.1590/1413-81232015211.09912014 
9. Ministério da Saúde (BR). Portaria n 1459, de 24 de junho de 2011. Institui no âmbito do Sistema Único de Saúde - SUS - a Rede Cegonha [Internet]. Brasília; 2011 [cited 2018 Feb 2]. Available from: http://bvsms.saude.gov.br/bvs/saudelegis/gm/2011/prt1459_24_06_2011.html

10. Ministério da Saúde (BR). Decreto-Lei 94.406, de 8 de junho de 1987. Regulamenta a Lei no 7.498, de 25 de junho de 1986, que dispõe sobre o exercício da enfermagem, e dá outras providências [Internet]. Brasília: 1987 [cited 2018 Feb 2]. Available from: http://www.planalto.gov. br/ccivil_03/decreto/1980-1989/D94406.htm

11. Matos JC, Lima RRS, Nakata CRG, Castro AF, Silva AR. The nursing education in teaching and nursing practice: integrative review. J Nurs UFPE On Line. 2016; 10(7): 2656-68. doi: 10.5205/reuol.9106-80230-1-SM1007201645.

12. Freitas LV, Teles LMR, Lima TM, Vieira NFC, Barbosa RCM, Pinheiro AKB, et al. Physical examination during prenatal care: construction and validation of educational hypermedia for nursing. Acta Paul. Enferm. 2012;25(4):581-588. doi: 10.1590/S0103-21002012000400016

13. Silveira MS, Cogo ALP. The contributions of digital technologies in the teaching of nursing skills: an integrative review. Rev Gaúcha Enferm. 2017;38(2):e66204. doi: 10.1590/1983-1447.2017.02.66204

14. Avelino CCV, Costa LCS, Buchhorn SMM, Nogueira DA, Goyatá SLT. Teaching-learning evaluation on the ICNP® using virtual learning environment. Rev Bras Enferm [Internet]. 2017;70(3): 602-9. doi: 10.1590/0034-7167-2016-0545

15. Tavares APC, Leite BS, Silveira IA, Santos TD, Brito WAP, Camacho ACLF. Analysis of Brazilian publications on distance education in nursing: integrative review. Rev Bras Enferm [Internet]. 2018;71(1):227-36. doi: 10.1590/0034-7167-2016-0454

16. Arreguy-Sena C, Marques TO, Souza LC, Alvarenga-Martins N, Krempser P, Braga LM, et al. Construction and validation of forms: systematization of the care of people under hemodialysis. Rev Bras Enferm [Internet]. 2018;71(2):379-90. doi: 10.1590/0034-7167-2015-0130

17. Lopes MVO, Silva VM, Araújo TL. Methods for establishing the accuracy of clinical indicators in predicting nursing diagnoses. Int J Nurs Knowledge. 2012;23(3):134-9. doi: 10.1111/j.2047-3095.2012.01213.x

18. Barbosa RC. Validação de um vídeo educativo para a promoção do apego entre mãe soropositiva para o HIV e seu filho [Tese][Internet]. Fortaleza: Universidade Federal do Ceará; 2008 [cited 2018 Feb 2]. Available from: http://www.repositorio.ufc.br/handle/riufc/2145

19. Alexandre NMC, Coluci MZO. Validade de conteúdo nos processos de construção e adaptação de instrumentos de medidas. Cienc Saúde Coletiva. 2011;16(7):3061-8. doi: 10.1590/S1413-81232011000800006

20. Polit DF, Beck CT. Fundamentos da pesquisa em enfermagem: avaliação de evidências para a prática de enfermagem. $7^{a}$ ed. Porto Alegre: Artmed, 2011.

21. Lira CAS, Castro FJL, Azevedo FHC. Métodos computacionais para o ensino em ciência da saúde: uma reflexão teórica. Saúde em Foco [Internet]. 2015 [Cited 2018 Mac 5];2(2):125-40. Available from: http://189.43.21.151/revista/index.php/saudeemfoco/article/view/532/858.

22. Frota NM, Barros LM, Araújo TM, Lopes MVO, Almeida PC, Caetano JA. Validação de hipermídia educativa sobre punção venosa periférica. Texto Contexto Enferm. 2015;24(2):353-61. doi: 10.1590/0104-07072015003480013

23. Lowman J. Dominando as técnicas de ensino. São Paulo: Atlas; 2004.

24. Worral PS. Avaliação da educação para a saúde. In: Bastable SB, editora. O enfermeiro como educador: princípios de ensino-aprendizagem para a prática de enfermagem. $3^{\text {a }}$ ed. Porto Alegre: Artmed; 2010. p. 579-613.

25. Guohong G, Ning L, Wenxian X, Wenlong W. The study on the development of internet-based distance education and problems. Energy Procedia. 2012;17(part B):1362-8. doi: https://doi.org/10.1016/j.egypro.2012.02.253

26. Dodt RCM, Ximenes LB, Oriá MOB. Validation of a flip chart for promoting breastfeeding. Acta Paul Enferm. 2012;25(2):225-30. doi: http:// dx.doi.org/10.1590/S0103-21002012000200011

27. Barbosa SFF, Marin HF. Web-based simulation: a tool for teaching critical care nursing. Rev Latino-Am Enferm. 2009;17(1):7-13. doi: 10.1590/ S0104-11692009000100002

28. Levi MD, Conrad FG. Usability testing of World Wide Websites sites [Internet]. Washington: U.S. Bureau of Labor Statistics, Office of Survey Methods Research; 2002. [cited 2015 Jan 08]. Available from: http://stats.bls.gov/ore/htm\%5Fpapers/st960150.htm.

29. Nielsen J. Projetando Websites. Rio de Janeiro: Campus; 2000.

30. Barboza EF, Nunes EM, Sena NK. Websites governamentais, uma esplanada à parte. Ci Inf. 2000;29(1):118-25. doi: 10.1590/ S0100-19652000000100012 